\title{
MASYARAKAT VIRTUAL, MITOS DAN PERILAKU KONSUMTIF
}

\author{
Marlin Christina Laimeheriwa
}

\begin{abstract}
The massive development of digital technology has spawned a variety of social media devices and has formed virtual society as well. The virtual society represents the new model of social interaction. This social interaction produces heterogeneity of meaning, while the meaning has been changing. The existence of meanings is determined by the response of virtual society, how they preserve, refuse and produce the meanings. Therefore, virtual society become the producer, agents, and consumer of meanings at once, the discourse of meaning turn into myth later. The myth affects the way people think in taking virtual reality as true reality. This is showing an epistemic problem in corresponding to the origin of reality. This phenomenon is highly visible in digital market. This paper aims to show the relation between virtual society, myth production, and its impact on consumptive behaviour. In taking a perspective in philosophy, postmodern perspective is used to explain and analyze the condition of virtual society, myth and consumptive behaviour. This paper describes few points from philosophical perspective: first, the virtual community as producer, an agent and consumer of knowledge and myth; Second, consumptive behaviour is one of the results of myths. In addition, this paper suggests the need for critical awareness to be able to identify the hidden motives of capital in selling commodities.
\end{abstract}

Keywords : Virtual society, Myth, Consumptive behavior, Postmodernism

\begin{abstract}
Abstrak
Perkembangan besar teknologi digital telah melahirkan berbagai perangkat media sosial dan telah membentuk masyarakat virtual juga. Masyarakat virtual mewakili model interaksi sosial baru. Interaksi sosial ini menghasilkan heterogenitas makna, sementara makna telah berubah. Keberadaan makna ditentukan oleh respon masyarakat virtual, bagaimana mereka melestarikan, menolak dan menghasilkan makna. Oleh karena itu, masyarakat virtual menjadi produsen, agen, dan konsumen makna sekaligus, wacana makna berubah menjadi mitos kemudian. Mitos mempengaruhi cara orang berpikir dalam mengambil realitas virtual sebagai realitas sejati. Ini menunjukkan masalah epistemik sesuai dengan asal mula realitas. Fenomena ini sangat terlihat di pasar digital. Tulisan ini bertujuan untuk menunjukkan hubungan antara masyarakat virtual, produksi mitos, dan dampaknya terhadap perilaku konsumtif. Dalam mengambil perspektif dalam filsafat, perspektif postmodern digunakan untuk menjelaskan dan menganalisis kondisi masyarakat virtual, mitos dan perilaku konsumtif. Makalah ini menjelaskan beberapa poin dari perspektif filosofis: pertama, komunitas virtual sebagai produsen, agen dan konsumen pengetahuan dan mitos; Kedua, perilaku konsumtif adalah salah satu hasil mitos. Selain itu, tulisan ini menunjukkan perlunya kesadaran kritis untuk dapat mengidentifikasi motif tersembunyi dari modal dalam menjual komoditas.
\end{abstract}

Kata Kunci : Masyarakat virtual, Mitos, Perilaku konsumtif, Postmodernisme 


\section{PENGANTAR}

Perkembangan teknologi analog menuju teknologi digital dalam dunia informasi secara perlahan memengaruhi dan mengubah setiap dimensi kehidupan manusia. Pengaruh dan perubahan itu berlaku pada nilai-nilai budaya, praktik sosial-ekonomi, tradisi-tradisi, dan bentuk-bentuk keyakinan, serta sistem kepercayaan. Era digital informasi berhasil menjadikan bisikan beruntun informasi menjadi latar kehidupan manusia. Informasi dengan perlahan dan tanpa hentinya membanjiri manusia di dalam hujan listrik yang tidak kasat mata. ${ }^{1}$

Pengaruh dan perubahan itu pun tidak lepas dari hasil interaksi antar manusia yang pada akhirnya menghasilkan makna baru atas kehidupannya. Pemaknaan baru kemudian menentukan pembentukan praktik sosial yang baru atau bentuk interaksi yang baru. Salah satu bentuk interaksi sosial baru dewasa ini adalah bentuk interaksi sosial di ruang virtual. Bentuk interaksi ini terwadahi melalui teknologi informasi digital yang menarik manusia berpartisipasi didalamnya secara massal. Dengan berpartisipasinya masyarakat di ruang virtual, maka kecenderungan interaksi sosial yang lain pun terjadi, seperti interaksi sosial ekonomi yang membentuk pasar digital (digital market).

Fenomena pasar digital ini pun perlahan menjadi satu sumber dan ruang pemberi makna baru dalam interaksi sosial yang aktual. Di dalam fenomena pasar digital, pemaknaan terhadap komoditas sebagai objek konsumsi menjadikan manusia semakin tumpul membedakan realitas aktual (physical reality) objek dan realitas objek yang dimitoskan. Ini menunjukkan pengetahuan koresponden tidak lagi memadai untuk mendasari bentuk kebenaran yang dikontestasikan dalam ruang virtual. Sebaliknya, opini semakin diyakini sebagai bentuk kebenaran universal. Pendasaran kebenaran model ini pun bukan pada prinsip verifikasi, melainkan pada kuantitas opini masyarakat virtual. Makin banyaknya respons dari masyarakat virtual terhadap suatu fenomena, objek, atau pun wacana, maka semakin meyakinkan suatu objek atau komoditas itu. Misalnya, suatu iklan perumahan menawarkan lokasi dan bentuk pemukiman disertai dengan konsep tertentu, seperti perumahan hijau dan hutan kota. Di tambah lagi, wajah iklan dihiasi dengan berbagai kualitas-kualitas yang melengkapi objek. Padahal, di balik proyek perumahan ini terdapat penggusuran lahan subur, hutan, dan pegunungan hijau yang sebenarnya. Namun, kenyataan ini sudah tidak lagi 
dihiraukan dan disadari oleh konsumen. Konsumen hanya mengonsumsi realitas kedua atau tanda konotatif, bahkan dibagikan secara massal di ruang virtual, sehingga konsumen sesungguhnya menjadi bagian dari produsen makna, atau tanda di ruang virtual.

Keberadaan kondisi masyarakat ini sesungguhnya sama dengan yang digambarkan oleh Lyotard sebagai masyarakat posmodern. Masyarakat postmodern ditandai dengan transformasi teknologi yang berpengaruh besar pada pengetahuan. Miniaturisasi dan komersialisasi mesin telah mengubah cara memperoleh, klasifikasi, penciptaan, dan eksploitasi pengetahuan. ${ }^{2}$ Proses demikian pada akhirnya membentuk mitos bersama dan diyakini sebagai kebenaran bersama. Keyakinan inilah yang mendukung keberadaan penyamaran mitos. Kebenaran dari mitos tidak lagi dipertanyakan melainkan didasarkan pada intensitas dan respons masyarakat dalam menghayati dan menggunakan mitosmitos tersebut. Kebenaran terselubungi di dalam permainan bahasa mitos sehingga masyarakat dikaburkan dengan realitas permukaan (surface).

Tulisan ini mendiskusikan keberadaan masyarakat virtual dengan menggunakan perspektif Lyotard untuk menyajikan bentuk-bentuk perubahan di era posmodern. Posmodernisme menyajikan keadaan masyarakat yang dilimpahi dengan beragam kebenaran, kebenaran bukan lagi homologi melainkan paralogi. Di sisi lain, permainan bahasa turut mendukung realitas kebenaran ini sehingga keadaan masyarakat posmodern menjadi semakin kompleks. Bentuk kebenaran da permainan bahasa ini pada gilirannya mendukung terbentuknya produksi mitos di ruang virtual, dan dampaknya pada perilaku konsumtif.

\section{KERANGKA TEORITIK}

Tulisan ini menggunakan teori postmodernisme yang diwakili oleh Jean Franscois Lyotard. Posmodrnisme menjelaskan bahwa masyarakat dewasa ini berhadapan dengan kebenaran semakin tereksploitasi. Eksploitasi kebenaran tentu saja tidak terlepas dengan perkembangan dunia industri yang terkomputasi.Locus kebenaran tidak lagi menjadi referensi, melainkan bagaimana kebenaran itu ditampilkan jika merujuk pada istilah posmodern secara khusus. Posmodernisme, akhiran "isme"menunjuk pada kritik-kritik filosofis atas gambaran dunia (world view), epistemologi dan ideologi-ideologi modern, sedangkan postmodernitas 
menunjuk pada situasi dan tata sosial produk teknologi informasi, globalisasi, fragmentasi gaya hidup, konsumerisme yang berlebihan, deregulasi pasar uang dan sarana publik, usangnya negara bangsa dan penggalian kembali inspirasiinspirasi tradisi.

Lyotard dengan analisanya tentang teknologi digital dan pengaruhnya itu tertuang dalam bukunya A Report Postmodern Condition. Karya ini menampilkan beberapa kondisi yang menjadi ciri dari masyarakat posmodern. Salah satunya adalah kondisi transisi pengetahuan. Bagi Lyotard, pada akhir abad ke-20 pengetahuan menjadi kekuatan produksi.Transisi pengetahuan ini tentu saja bersamaan dengan kebaruan budaya dan kondisi ekonomi yang ditandai dengan krisis legitimasi dan ketidakpercayaan terhadap metanarasi. Ketidakpercayaan terhadap metanarasi inilah yang pada gilirannya menghasilkan ruang lahirnya narasi-narasi baru tentang kebenaran. Namun, Lyortard menambahkan bahwa praksis kritik harus harus diganti dengan "paralogi" yang pragmatis, atau dengan perhatian pada kontrol tanpa batas, konflik yang ditandai dengan ketidaklengkapan informasi, "fracta", katastrofi dan paradoks-paradoks pragmatis.

Di sini, Lyotard membuat pemisahan antara mengetahui yang partikular dari memahami totalitas, ini hampir menjadi standar aturan analisis budaya kontemporer yang mendefinisikan budaya sebagai persaingan yang cair, tetapi tidak sepenuhnya terikat oleh wacana. Dari sudut pandang ini, dapat dipahami bahwa membaca kebudayaan dengan mereduksinya pada persoalan ekonomipolitik pada akhirnya tidak mampu mengenali beragam model budaya beroperasi pada level lokal sebagai ruang perlawanan terhadap status quo. ${ }^{3}$

Untuk mengkaji masyarakat virtual, sekiranya perlu dijelaskan beberapa kondisi masyarakat postmodern yang turut membentuk perilaku konsumtif. Pertama, bidang pengetahuan yang terkomputasi. Pengetahuan mendapat pengaruh besar dari transformasi teknolog, yaitu cara memperoleh, klasifikasi, dan eksploitasi pengetahuan telah berhasil berubah dengan adanya pengaruh dari miniaturisasi dan komersialisasi mesin. Segala model pengetahuan yang tidak dapat diterjemahkan dalam bahasa mesin tidak dapat digunakan. Proses pembentukan pengetahuan melalui pelatihan pikiran sebagai hakikat dari pengetahuan itu sendiri digantikan dengan fungsi pragmatis pengetahuan. Akibatnya, pengetahuan dan kekuatan produksi dewasa ini menjadi identik. 
Pengetahuan komputasi ini menentukan komposisi sebagian besar tenaga kerja dalam ruang lingkup semua profesi semakin meningkat. Oleh karena itu, pengetahuan sebagai bagian dari alat kekuasaan. Dalam dunia ekonomi global, penguasaan atas informasi menentukan kapasitas produksi bahkan distribusi. ${ }^{4}$

Kedua, persaingan pengetahuan ilmiah dan pengetahuan narasi. Pengetahuan ilmiah mendapat kedudukan yang sangat penting dalam dunia modern. Pengetahuan ilmiah mewakili prosedur yang sistematis dan bahasa denotatif atau logis dan kognitif. Hukum verifikasi menjadi dasar legitimasi pengetahuan ilmiah dalam konsensus ilmuan. Memang tidak semua konsensus merupakan tanda kebenaran, tetapi kebenaran suatu pernyataan pasti menciptaan konsensus. Alhasil, pengetahuan yang sistematis, logis dan verifikatif ini mempengaruhi epistemologi modern yang menuntut suatu totalitas dan objektivitas. Namun, dalam dunia posmodern para ilmuan membutuhkan penerima pesan yang dapat melegitimasi pernyataan mereka. Pengetahuan ilmiah ini tentu saja berhadapan dengan narasi. Pengetahuan narasi (cerita populer, mitos, legenda, dan dongeng) yang menolak totalitas pengetahuan. Narasi pada zaman pra modern mendapat tempat penting, karena melegitimasi lembagalembaga sosial atau merepresentasikan model-model integrasi, baik positif maupun negatif, kedalam lembaga yang ada. Di dalam masyarakat tradisional, tradisi narasi juga merupakan tradisi criteria yang menentukan kompetensi bersisi tiga, yaitu pengetahuan teknis (knowing-how), pengetahuan cara bicara (knowing how to speak), dan cara mendengarkan (knowing how to hear), yang digunakan masyarakat untuk berhubungan dengan dirinya sendiri dan lingkungan. Dalam bentuk narasi, pernyataan-pernyataan tentang kebenaran, keadilan, dan keindahan sering berhubungan. Apa yang disampaikan melalui narasi adalah seperangkat aturan yang membentuk ikatan sosial. ${ }^{5}$

Jika di zaman modern, narasi mendapat kemunduran, setidaknya dalam kondisi posmodern narasi mendapat angin segar. Berperannya permainan bahasa yang menekankan pentingnya konteks dan pemaknaan. Kondisi ini tentu saja pada gilirannya tidak dapat dilepaspisahkan dari ekspansi kapital dalam model baru. Jika di zaman modern kapital menerapkan produksi sebagai kekuatan utama, maka di zaman posmodern kekuatan produksi sama pentingnya dengan kekuatan konsumsi. Fenomena ini tentu saja tidak lepas dari kehadiran masyarakat virtual 
yang bukan saja berfungsi sebagai konsumen informasi melainkan juga sumber legitimasi dan sumber pembentuk kekuatan produksi.

Selain itu, postmodern memungkinkan apa yang menjadi masalah sosiologis muncul kembali dalam agenda intelektual. Dalam arti keadaan posmodern menantang visi strukturalis yang memandang masyarakat secara sempit, dengan menelaah kedalaman realitas pengalaman sebagai titik awal memahami kompleksitas realitas yang begitu luas, sehingga satu produk konseptual sulit untuk bertahan di dalam masyarakat posmodern ini, khususnya masyarakat virtual.

\section{MASYARAKAT VIRTUAL}

Eksistensi masyarakat virtual tentunya merupakan perkembangan lanjut dari keberadaan masyarakat sebelumnya. Perkembangan itu disaksikan dan dialami oleh masyarakat itu sendiri, tanpa terkecuali perkembangan dan kebaruan teknologi. Perkembangan dan kebaruan itu menjadi bagian sesungguhnya dari keinginan masyarakat untuk bertahan dan menikmati kehidupannya sekaligus untuk memodifikasi kehidupannya. Hasil pemodifikasian itu pun sebaliknya mempengaruhi sistem interaksi manusia.

Steve Wolgar dalam pengantar buku Virtual Society: Technology, Cyberbole and Reality menyebutkan bahwa perkembangan masif teknologi ini mengubah dan mentransformasi hakikat atau dasar semua aspek kehidupan manusia, sehingga manusia seharusnya memikirkan kembali bagaimana dimensidimensi kehidupan manusia dapat terhubung dengan kebaruan teknologiteknologi itu. Terlebih khusus kebaruan informasi yang secara terus menerus, sehingga mempertanyakan kembali perekat apa yang dapat menguatkan relasi sosial manusia sebagai individu, komunitas, atau kelompok di masa-masa mendatang. ${ }^{6}$ Mempertanyakan perekat sosial ini, berarti mempertanyakan kembali hakikat masyarakat, atau dasar-dasar fundamental pembentukan masyarakat, serta ciri dasar yang membedakan masyarakat tradisional dan masyarakat virtual.

Definisi masyarakat tentu telah banyak di bahas oleh para sosiolog maupun ilmu sosial pada umumnya. Secara umum masyarakat adalah organisasi yang dibentuk oleh orang-orang yang terdiri dari individu maupun kelompok. Selain itu, di dalam masyarakat terdapat beragam struktur atau hubungan sosial yang 
membentuk masyarakat. Hubungan-hubungan sosial itu terdiri dari status, peran (role), norma dan sanksi, nilai, organisasi formal dan informal, institusi, budaya, serta organisme. $^{7}$ Aguste Comte yang mengadopsi gagasan Aristoteles menjelaskan bahwa pada dasarnya masyarakat harus dilihat sebagai orde, yaitu susunan yang tetap dan tertib. Orde itu dilatarbelakangi oleh kenyataan bahwa manusia saling membutuhkan dan saling melengkapi sesuai dengan kemampuan mereka masing-masing. Tiap-tiap orang dan tiap-tiap golongan yang mempunyai tugas dan kewajiban masing-masing, sehingga masyarakat tersusun atas prinsip pembagian tugas. Oleh karenanya, orde adalah keadaan normal yang bertumpu pada sifat sosial manusia (zoon politicon). Selanjutnya, masyarakat dilihat melalui tahap evolusi, dalam hal ini masyarakat dilihat sebagai kesatuan perkembangan akal budi yang dapat dibedakan menjadi tiga tahap, yaitu tahap religius, tahap metafisik dan tahap positif. ${ }^{8}$

Masyarakat di sisi lain dalam pandangan Marx bergulat dalam perjuangan kelas. Masyarakat itu terdiri dari orang bebas dan budak, kaum bangsawan dan orang rendahan, tuan dan hamba, pemimpin dan pekerja, penindas dan yang ditindas. Marx menyebutkan misalnya, pada masa awal feodal yang terepresentasi pada kekuasaan kaum bangsawan, yang kemudian runtuh dan memunculkan kelas borjuis. Kelas-kelas baru tercipta, kondisi-kondisi baru bagi penindasan dan bentuk-bentuk perjuangan yang baru menggantikan yang lama. Kondisi ini semakin buruk di zaman modern, karena masyarakat secara keseluruhan semakin terbagi kedalam kedua kubu besar yang saling bermusuhan, yaitu kaum borjuis dan kaum proletar. Pengarah sistem industri feodal digantikan dengan kelompokkelompok elit baru. ${ }^{9}$ Revolusi dalam industri pun terjadi, rekayasa monopoli kekuasaan merambah dalam kesadaran sebagai sesuatu yang normal. Posisi manufaktur yang tadinya dikuasai oleh kaum bangsawan kini berubah menjadi industri raksasan modern, posisi kelas menengah industrial digantikan oleh para milyuner industrial-kaum borjuis modern. Ketahanan masyarakat borjuis ini tidak akan bertahan jika tidak didukung oleh sarana-sarana produksi, sistem hubungan produksi yang direvolusionerkan sebagai salah satu prasyarat. ${ }^{10}$

Dari beberapa penjelasan tentang masyarakat dari para filsuf, bagaimana dengan masyarakat virtual? Masyarakat virtual adalah masyarakat yang hidup di era teknologi digital. Masyarakat di zaman ini menganggap bahwa teknologi- 
teknologi ini sebagai dues ex machine - sebagai sumber atau entitas penting untuk menyelesaikan semua kontradiksi sosial. Jika demikian, maka manusia mengalami perubahan fundamental dalam hidup, yang akhirnya memerlukan cara baru untuk memahami dunia. Hal ini juga menjadi kritik bagi model dan teori-teori terdahulu, khususnya yang berfokus pada pembagian kelas dalam masyarakat dan tuntutan akan kesetaraan. ${ }^{11}$ Namun, Wilke justru menempatkan dunia digital justru berdampingan dengan konflik antar kelas dengan alasan bahwa apa yang direpresentasikan dunia digital pada kenyataannya adalah manifestasi teknologi dan budaya yang mendasari kelas dan kemudian terungkapkan melalui wacana dominasi digital. $^{12}$

Berkaitan dengan kepentingan bisnis, Nagel mengungkapkan bahwa internet bukan sekedar penanda kecepatan informasi dan kemurahan informasi melainkan menyediakan platform baru untuk menunjang pasar dan interaksi bisnis yang sangat atraktif. Bukan hanya membangun jaringan antar personal dan komunitas tetapi dapat merekayasa kesamaan kebutuhan bersama. Oleh karenanya, komunitas virtual didefinisikan dengan menyatukan orang dengan seperangkat kebutuhan atau minat bersama. Kebutuhan atau minat itu bisa menjangkau berbagai dimensi. Komunitas virtual dapat diatur di sekitar area minat (seperti olahraga atau investasi saham), segmen demografi (kelompok usia tertentu dalam populasi), atau wilayah geografis (wilayah metropolitan). Di samping itu, Nagel meyakini bahwa memiliki relevansi untuk pasar bisnis-ke-bisnis. Dalam situasi seperti itu, komunitas virtual dapat didefinisikan di sekitar industri, jenis kategori pekerjaan tertentu (misalnya, manajer pembelian perusahaan besar), atau mungkin jenis bisnis (bisnis berbasis rumah kecil atau waralaba). Bagaimanapun, intinya adalah untuk menciptakan fokus bersama untuk mengumpulkan pelanggan bersama-sama yang memiliki kekhawatiran dan persyaratan yang sama. ${ }^{13}$ Jadi homogenitas kebutuhan dijadikan sebagai salah satu dasar interaksi masyarakat di ruang virtual. Dasar itulah yang memeberi secara tidak langsung legitimasi masyarakat di ruang virtual.

Dalam konteks pasar digital, permainan bentuk kebenaran atau mitos sangatlah mendominasi. Bentuk kebenaran, legitimasi dan permainan opini tergiring dan terus berubah bergantung pada permainan wacana yang terjadi di dalam ruang virtual. Permainan wacana ini perlahan membentuk mitos-mitos yang 
berpengaruh terhadap perilaku konsumsi. Kehadiran masyarakat virtual adalah bagian dari perluasan jangkauan kapital dan kemajemukan realitas, sehingga memahami masyarakat digital yang hanya bertolak dari satu teori tentang masyarakat tidaklah memadai.

Jika dilihat masyarakat virtual sebagai masyarakat posmoderen keberadaan itu dapat disandingkan dengan dunia komputasi yang semakin memadai dan permainan bahasa melalui mitos dan produksi opini serta kebenaran-kebenaran baru. Ciri khas masyarakat virtual tidak lagi ditandai dengan salah satu model dalam rujukan Comte, semuanya melebur menjadi satu mengaburkan demarkasi. Namun, jika merujuk pada Marx, kenyataan kelas berdasarkan kepemilikan modal tentunya masih berpengaruh terhadap hadirnya dunia komputerisasi dan pasar digital sebagai hasil dari ekspansi kapital.

\section{MITOS DAN PASAR DIGITAL}

Penjelasan tentang hakikat masyarakat dalam frame tradisional, modern, maupun posmodern kemudian mengarahkan kita untuk melacak keberadaan kapital dalam di abad ini. Bagaimana eksistensi kelas borjuis di abad ke-21? Apakah grand narasi berhasil pula meruntuhkan eksistensi kaum borjuis masyarakat?

Sebagaimana yang menjadi salah satu ciri masyarakat posmodern yang dijelaskan oleh Lyotard bahwa permainan bahasa menjadi salah satu penanda. Permainan bahasa kebenaran di era digital, khususnya dalam ruang virtual sangatlah ditentukan oleh penggiringan opini (doxa) dari masyarakat virtual. Representasi penggiringan itu tentu saja masih diwakilkan oleh jumlah dan frekuensi wacana itu sering ditampilkan di dalam ruang virtual. Dalam konteks pasar digital di dalam ruang virtual, opini tentu saja memainkan peranan penting sebagai energi pendorong melariskan suatu produk konsumsi. Namun, konten wacana atau isi wacana suatu produk konsumsi bukan lagi didasarkan hanya pada orientasi kebutuhan produk itu bagi konsumen tetapi justru dilapisi dengan mitosmitos populer. Namun, kelahiran mitos populer tentu saja merupakan motif kapital untuk memperoleh surplus yang berkedok, yang mensugesti konsumen untuk menerima suatu produk konsumsi dengan segala sampul dan hiasannya. Persoalan ini bukan hanya terjadi dalam ruang virtual melainkan telah berakar 
sebelumnya dalam interaksi sosial yang aktual, sehingga motif kapital justru memperoleh wadah yang lebih efektif.

Untuk menelisik eksistensi kaum kapital dalam strategi perluasan pasarnya maka tentulah bersandar pada mekanisme pasar. Pada dasarnya persoalan ekonomi menyangkut tiga hal yaitu produksi, distribusi, konsumsi. Produksi pada umumnya merupakan kegiatan atau aktivitas menciptakan suatu benda atau menambah kegunaan dari suatu benda. Namun, bagaimanapun objek tidak dapat dibuat oleh manusia, tidak juga massa materi, sehingga yang bisa dilakukan manusia adalah memproduksi kembali material yang ada, dibawah bentuk lain, dan memberikan utiltas yang tidak dimiliki sebelumnya, atau hanya menambah utilitas lain yang belum ada sebelumnya. Pada kenyataannya, yang diciptakan bukan materi, melainkan utilitas.

Dalam pengertian ini maka, kata produksi harus dalam perkembangan wacana ekonomi politik. Produksi adalah ciptaan, bukan materi, tetapi utilitas. Benda tidak diestimasi berdasarkan panjang, besar atau berat dari produk, tetapi oleh utilitas yang disajikannya. Meskipun harga adalah ukuran dari nilai barang, dan kegunaannya. Hal in pun terasa absurd dalam menarik inferensi, bahwa dengan menaikkan harga secara paksa, utilitas mereka bisa ditambah. Artinya, harga menentukan kualitas. Nilai tukar, atau harga, adalah indeks yang dikenal utilitas suatu hal, begitu lama hanya karena transaksi manusia dibebaskan dari setiap pengaruh tetapi dari utilitas yang identik. ${ }^{14}$ Inilah tanda dari bekerjanya mitos dan produksi kebenaran. Realitas baru diadakan dari kenyataan adaan sehingga terjadi patahan pengetahuan.

Kenyataan ini berlaku dalam konteks masyarakat digital dan dalam konteks pasar digital. Kegunaan suatu benda masih tetap menjadi prioritas, tetapi penambahan sejumlah utilitas sekunder pada akhirnya menjauhkan utilitas primer dari objek tersebut. Motif kapital menjadikan suatu produk kaya dengan fungsifungsi sekunder. Misalnya, iklan lokasi pemukiman di daerah tertentu dengan menawarkan dengan konsep lokasi yang nyaman, aman dan strategis serta dilengkapi dengan beberapa Mall dan rumah sakit. Dari contoh ini, tentu dapat terlihat jelas bahwa pemukiman yang nyaman, aman serta strategis merupakan kebutuhan dasar dan kualitas dari suatu hunian, tetapi penambahan mall dan Rumah sakit dengan fasilitas mewah tentu saja menjadikan lokasi perumahan ini 
sebagai lokasi perumahan yang bukan hanya nyaman melainkan juga representasi dari masyarakat dengan kelas sosial tertentu. Ini menunjukkan fungsi mitos bergerak dimulai dari proses produksi.

Kedua, distribusi yang pada umumnya merupakan kegiatan menyalurkan atau menyebarkan hasil produksi. Persoalan distribusi berkaitan erat dengan sistem permintaan (demand) dan penawaran (supply) yang saling memengaruhi. Intensitas permintaan dan penawaran merupakan dasar dari harga pada setiap tindakan pertukaran; untuk harga, itu akan diingat, hanyalah arus nilai yang diperkirakan dalam uang. Permintaan untuk semua objek kesenangan, atau utilitas tidak akan terbatas. Di samping itu, pasokan tidak akan terbatas, jika tidak dibatasi oleh keadaan yang. Sehingga, tidak diragukan lagi bahwa apa pun yang bisa diproduksi akan diproduksi tanpa batas kuantitas, selama hasil produksi itu sebanding dengan pembeli. ${ }^{15}$ Dari proses distribusi dalam dunia digital, skala permintaan dan penawaran tidaklah sulit untuk ditemukan. Pada level ini distribusi, mitos tetap memainkan fungsinya. Dalam masyarakat virtual, distribusi informasi dan produk sangat cepat. Distribusi informasi tentunya antar komunitas virtual dibumbui dengan mitos-mitos produksi, sebagaimana biasanya. Namun, semakin banyak respons dari masyarakat virtual, menentukan permintaan dan penawaran terhadap produk tersebut. Orientasi distribusi disini bukan hanya persoalan orientasi kebutuhan melainkan juga orientasi terbalik, dalam arti pengenalan suatu identitas atau sumber produksi.

Ketiga, konsumsi adalah kegiatan menggunakan atau memanfaatkan hasil produksi dengan tujuan memenuhi kebutuhan. Pada masyarakat posmodern, tujuan konsumsi tidak hanya untuk memenuhi kebutuhan melainkan juga menjadi objek kesenangan. Kondisi posmodern ditandai dengan realitas bayangan, tanda dimana media, dan budaya populer yang ditampilkan di ruang virtual semakin mempengaruhi segala macam hubungan sosial, tanda budaya media semkin mendominasi realitas. Selain itu, terkait masalah konsumsi, kesulitan ditemui untuk membedakan atau memilah antara ekonomi dan budaya populer, apa yang dibeli dan dikonsumsi semakin dipengaruhi oleh budaya populer yang merupakan produk kaum kapital. Salah satu implikasi utama adalah di dalam posmodern, tampilan permukaan gaya lebih penting daripada substansi, yang pada gilirannya menuntut ideologi perancang. Dengan argumen bahwa masyarakat semakin 
mengonsumsi citra maupun tanda itu sendiri bukan manfaatnya, atau mengabaikan kegunaannya. Selain itu, realitas virtual memungkinkan orang mengalami berbagai macam bentuk hasil produksi secara tidak langsung, dan karena itu rangsangan-rangsangan permukaan itu secara potensial dapat menggantikan rangsangan nyata. ${ }^{16}$ Penghayatan realitas pada tataran permukanan ini pada akhirnya menumpulkan nalar kritis. Pembiasaan terhadap nalar dangkal mengoyakan kebenaran dan memuliakan mitos.

Kenyataan konsumsi di era digital menunjukkan kesadaran realitas yang terdistorsi. Kenyataan primer tidak menjadi sumber utama dalam refleksi kebenaran melainkan tertutup dan tergantikan dengan bayangan realitas yang dianggap sebagai kebenaran utama dalam interaksi sosial. Masyarakat termabukan dengan makanan-makanan informasi yang tidak terhingga, kerumitan kronologi yang tidak berdasar, dan hancurnya kerinduan terhadap pesona kebenaran dan makna. Ini tentu saja telah menjadi suatu gaya hidup di era ini, suatu gaya populer.

\section{KRITIK TERHADAP PERILAKU KONSUMTIF DAN KESADARAN YANG TERDISTORSI}

Keserakahan melahap segala informasi tanpa filter melahirkan perilaku konsumtif yang tersebar secara universal. Keadaan dewasa ini dikaitkan dengan terbentuknya budaya populer, yang dalam pandangan posmodern dianggap sebagai kegamangan-kegamangan maupun distorsi-distorsi. Terdistorsi artinya tidak menampilkan koherensi antar ruang dan waktu. ${ }^{17}$ Artinya, kemunculan realitas-realias seakan terpisah dari linearitas sejarah. Matinya metanarasi mengakibatkan sejumlah narasi-narasi kecil bermunculan disertai dengan kegamangan-kegamangan konsumtif yang menyerap semua realitas tanpa filter. Kesadaran-kesadaran ini sesungguhnya menunjukkan terdistorsinya kesadaran kritis yang terepresentasi, salah satunya melalui penangkapan realitas objek.

Keadaan ini sesungguhnya merupakan salah satu implikasi melepaskan diri dari ruang "modernitas" yang terkesan monoton dan tidak membiarkan individu bebas meramu kebenaran. Posmodern dengan sukarela memberikan ruang kebebasan bagi hadirnya berbagai macam narasi-narasi baru. Manusia dianggap sebagai subjek yang bebas dan selektif, sehingga mampu membuat keputusan saat 
berhadapan dengan kelenturan-kelenturan semiotik. Kenyataan ini dilegitimasi dengan alibi "mentalitas bebas memilih". Bagi lawan posmodern, mentalitas ini tidak lain memainkan secara langsung ideologi "pasar bebas". ${ }^{18}$ Suatu legitimasi moral kapital yang terus meyebar di setiap dimensi kehidupan.

Ideologi ini tersebar melalui beragam gaya yang ditampilkan melalui media analog maupun digital. Suatu gaya populer yang disuburkan melalui televisi, film, seni, dan lainnya. Hal ini terlihat ketika pengaruh perusahan yang memayungi media informasi dan komunikasi lebih berpengaruh, dibandingkan dengan lembaga pengatur publik, padahal isi komunikasi tidak menampilkan dimensi revolusioner dan terus melayani kepentingan bisnis. Iklan sesungguhnya memilki pengaruh provokatif untuk mentransformasi realitas sosial yang timpang, tetapi kenyataan dewasa ini menunjukkan realitas subordinatif. Misalnya, iklan tertentu menyubordinasikan inovasi budaya dan dijadikan sebagai hiburan demi kepentingan komersial atau pun sebaliknya menjadikan inovasi budaya di level permukaan demi kepentingan bisnis. ${ }^{19}$ Jika demikian, maka pelumpuhan nalar kritis semakin subur. Kebutuhan manusia untuk bahagia dan terhibur dijadikan sarana komersial semata melalui informasi-informasi yang tidak bermuara pada kebenaran hakiki. Hiburan hanyalah hiburan tanpa bonus pengetahuan.

Keberlangsungan sikap terhadap budaya massa pada abad ke-20 paling jelas oleh Theodor Adorno's dan Max Horkheimer dalam karya The Culture Industry: Enlightenment as Mass Deception. Dalam karya ini budaya massa layak dikecam karena diatur secara ketat oleh perusahan. Bagi Adorno dan Horkheimer, keseragaman merupakan ciri utama budaya populer dan budaya massa. Budaya populer mengenakan "label yang sama" dalam semua rangkaian ekspansinya. Film, radio, dan majalah membentuk sistem yang seragam secara keseluruhan dan di setiap bagiannya. Identik adalah identitas budaya massa. "Tidak ada perbedaan yang relevan di antara berbagai bentuk wacana yang ada, karena konsumen tidak melabeli atau membuat wacana, melainkan produsen. Ini merupakan suatu keadaan homogen yang dijamin melalui koordinasi yang ketat oleh pusat otoritas. ${ }^{20}$ Namun, kesadaran untuk membongkar konspirasi pasar universal ini telah dilumpuhkan oleh kesadaran individu pula karena kebutuhan yang berhasil direkayasa. Kebutuhan itu ditandai dengan keinginan untuk menolak yang absolut yang kegamangan menikmati keragaman. 
Selain itu, kritik lain datang dari feminisme. Stacy Gillis mengutip pemikiran Arlie Russel melalui karyanya In The Commercial Spirit of Intimate Life And The Abduction of Feminism. Disini, Arlie Russell Hochschild menyelidiki hubungan antara feminisme dan kapitalisme dengan saran personal dari sebuah studi kasus. Arlie mengilustrasikan bagaimana spesifikasi nilai-nilai feminis telah digunakan dalam wacana-wacana budaya untuk wanita, mendorong mereka untuk menjalani hidup mereka dengan cara yang mengafirmasi satu idealisme feminis, tentang kesetaraan, dan merendahkan yang lain, yaitu ikatan sosial yang kaya secara emosional'. Lanjutnya, Arlie menafsirkan ini sebagai bukti tren budaya kontemporer menuju pendinginan emosional. Sebagaimana dikatakannya, tren ini adalah suatu keanehan, suatu pergantian gaya yang masih pararel, sebagaimana yang dikatakan oleh Max Weber dalam karyanya The Protestant Ethic and the Spirit of Capitalism, "keluar dari gua" gereja justru berubah menjadi suatu sosok inspirasi semangat kapitalisme, gereja mengarahkan manusia untuk menghasilkan uang dan membangun kapitalisme. Demikian juga feminisme "keluar dari gua" gerakan sosial untuk menopang semangat komersial "keintiman hidup" yang pada dasarnya justru terpisah, bahkan asing baginya. ${ }^{21}$ Ini menunjukkan bahwa semua dimensi kehidupan dengan sengaja dan sadar dikomersialkan oleh kapital.

Jika sejumlah pemikiran menegaskan munculnya budaya massa atau budaya populer sebagai produk dari kaum kapital, maka benarlah kata Marx bahwa Bagi Marxisme pembicaraan tentang penindasan kapitalisme tidak bisa dilihat dari kacamata moral melainkan mencari dasar material dari penindasan itu. Semua perusahaan kapitalis memproduksi barang atau jasa, atau lebih tepatnya mereka memproduksi komoditas. Komoditas adalah barang atau jasa yang diproduksi untuk dijual. Sebelum berkuasanya kaum kapital, barang atau jasa diproduksi terutama untuk digunakan, bukan untuk dijual. Hari ini di bawah semangat kapital semua barang dan jasa adalah komoditas. Komoditas tentunya dibungkus dalam ideologi dan sampul sampul mitos kaum kapitalis.

\section{PENUTUP}

Masyarakat virtual merupakan masyarakat di era digital yang kini memegang peranan penting dalam menghasilkan dan mempengaruhi relasi sosial. 
Masyarakat virtual tidak mewakili model tertentu dari pendefinisian masyarakat oleh teori tertentu, melainkan merupakan irisan dari berbagai model masyarakat, walaupun presentasi ekpansi kapital masih menjadi bagian terbesar dari masyarakat virtual. Keduanya saling berhubungan dan melahirkan pasar digital. Pasar digital dan masyarakat digital berhasil memproduksi objek sekaligus mitos bersamaan sehingga memunculkan perilaku konsumtif. Perilaku konsumtif sesungguhnya merupakan pelumas bagi keberadaan kaum kapital, dan upaya pencarian surplus yang tidak pernah berakhir. Masyarakat virtual dan perilaku konsumtif merepresentasikan suatu keadaan dimana kebutuhan sama pentingnya dengan simbol. Keadaan ini sesungguhnya merepresentasikan lumpuhnya kesadaran kritis dan matinya nalar kebebasan. Kebenaran termanipulasi dalam simbol-simbol kapital yang terus merekayasa kebenaran dan membiarkan mitos sebagai kebenaran.

\section{Endnotes :}

\footnotetext{
${ }^{1}$ Luke Trendinik, Digital Information Culture: The individual and Society in digital Age, (London: Chandos Publishing, 2008), hlm. 21.

${ }^{2}$ Madan Sarup, Postrukturalisme dan Posmodernisme (Terj.), (Yogyakarta: Jalasutra, 2008), hlm. 207.

${ }^{3}$ Luke, op.cit., hlm. 23

${ }^{4}$ Madan Sarup, op.cit., hlm. 208

${ }^{5}$ Ibid., hlm. 210-211

${ }^{6}$ Steve Wolgar (ed), Virtual Society: Technology, Cyberbole, Reality, (United Kingdom: Oxford University Press, 2003), hlm. 2.

${ }^{7}$ Earl, R, Babbie, What is Society, (California: Pine Forge Press, 1994), hlm.21-22.

${ }^{8}$ K.J. Veeger, Realitas Sosial, (Jakarta: Gramedia, 1990), hlm. 19.

${ }^{9}$ Martin Suryajaya, Teks-Teks Kunci Filsafat Marx, (Yogyakarta: Resist Book, 2016) hlm. 96-97

${ }^{10}$ Ibid., hlm. 104.

${ }^{11}$ Rob Wilkie, The Digital Condition: Class and Culture in Information Network, (New York : Fordham University Press, 2011), hlm. 12.

12 Ibid., hlm. 2.

${ }^{13}$ Hagel John, "Expanding Markets Through Virtual Communities", Journal of Interactive Marketing, Vol. 13. No 1, John Wiley \& Sons, Inc, 1999.

${ }^{14}$ Say J. B. A treatise on Political Economy, (New York: agustus m. Kelly publisher, 2011), hlm. 64.

${ }^{15}$ Ibid., hlm. 69.

${ }^{16}$ Dominic Strinarti, Popular Culture, (Yogyakarta: Jejak, 2007), hlm. 257-258

${ }^{17}$ Ibid. hlm.260.

${ }^{18}$ Jim Collins, Uncommon Cultures, (New York: Routledge, 1989), hlm. 146.

${ }^{19}$ Manuel Castell, 2009, Communication Power, (London: Oxford, 2009), hlm. 9.

${ }^{20}$ Ibid, hlm. 10.

${ }^{21}$ Stacy Gillis \& Joane Hollows, Feminism, Domesticity, \& Populer Culture, (New York:

Routledge, 2008), hlm. 33.
} 


\section{DAFTAR PUSTAKA}

Babbie Earl, R, 1994. What is Society, California : Pine Forge Press.

Castell Manuel, 2009. Communication Power, London : Oxford.

Collins Jim, 1989. Uncommon Cultures, Routledge : New York.

Hagel John, "Expanding Markets Through Virtual Communities", Journal of Interactive Marketing, Vol. 13. No 1, John Wiley \& Sons, Inc, 1999.

J. B, Say, 2011. A treatise on Political Economy, New York : AGUSTUS M. KELLY PUBLISHER.

K.J. Veeger, 1990. Realitas Sosial, Jakarta : Gramedia.

Lechte John, 2001. 50 Filsuf Kontemporer, Yogyakarta : Kanisius.

Sarup Madan, 2008. Postrukturalisme dan Posmodernisme (terj.), Yogyakarta : Jalasutra.

Strinarti Dominic, 2007. Popular Culture, Yogyakarta : Jejak.

Trendinik Luke, 2008. Digital Information Culture: The individual and Society in digital Age, London : Chandos Publishing.

Wilkie Rob, 2011. The Digital Condition: Class and Culture in Information Network

Wolgar Steve (ed), 2003 Virtual Society: Technology, Cyberbole, Reality, United Kingdom: Oxford University Press

Stacy Gillis \& Joane Hollows, 2008. Feminism, Domesticity, \& Populer Culture, New York: Routledge.

Suryajaya, Martin, 2016. Teks-Teks Kunci Filsafat Marx, Yogyakarta : Resist Book. 